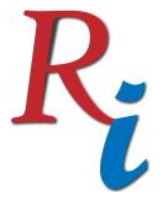

Asia Proceedings of Social Sciences

(APSS)

www.readersinsight.net/APSS

\title{
THE RELATIONSHIP BETWEEN SMALL AND MEDIUM ENTERPRISES (SMES) AND POVERTY IN NIGERIA
}

\section{Musa Mohammed}

Department of Project Management Technonoly

Federal University of Technology

Minna, Niger State, Nigeria

musamoh@futminna.edu.ng

\section{Rossazana Ab-Rahim*}

Faculty of Economics and Business

Universiti Malaysia Sarawak

Malaysia

arrossazana@unimas.my

*Corrosponding author's Email: arrossazana@ unimas.my

Peer-review under responsibility of $5 \mathrm{th}^{d}$ Asia International Conference 2019 Scientific Committee

http://connectingasia.org/scientific-committee/

(C) 2019 Published by Readers Insight Publisher, lat 306 Savoy Residencia, Block 3 F11/1,44000 Islamabad. Pakistan,

editor@ readersinsight.net

This is an open access article under the CC BY-NC-ND license (http://creativecommons.org/licenses/by-nc-nd/4.0/). 


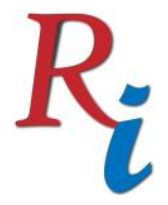

Asia Proceedings of Social Sciences

(APSS)

www.readersinsight.net/APSS

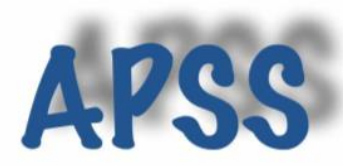

\section{A b s t r a c t}

This study examines the moderating role of youth empowerment on the relationship between Small and Medium Enterprises (SMEs) and Multidimensional Poverty Index (MPI) in Niger State, Nigeria. The main objective of the study is to delve into whether SMEs has substantial impact on the reduction of poverty in Niger State, Nigeria. A survey technique was employed and questionnaire was used to collect data from 432 SMEs owners in 8 selected Local Government Areas of Niger State, Nigeria. The Statistical Package for Social Sciences was used for descriptive analysis and Partial Least Square-Structural Equation Modelling (PLSSEM) is used for testing for hypotheses. The results showed that there are positive changes in the socio-economic status of the people due to their involvement in SMEs activities of employment, innovation, human capital development and income; the results showed that the moderating effect of youth empowerment has positive influence on the relationship between SMEs and MPI. The results imply that SMEs owners should be empowered to enable them have access to resources to finance their businesses; and greater effort should be accorded to the empowerment of youth so as to further reduce poverty in Nigeria.

\section{Research High I ight s}

The results demonstrate that there is a positive relationship between Small and Medium Enterprises and multidimensional poverty reduction. The involvement of households in various activities of SMEs enables their family members to have access to quality education, good health and an improved living standard.

The results also show that the moderating effect of youth empowerment strengthen the relationship between SMEs and multidimensional poverty reduction. The empowerment of youth makes them have access to resources which enables them to partake actively in various activities of SMEs which in the long-run hampers multidimensional poverty. 


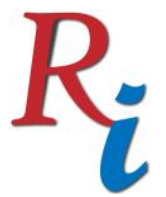

\section{Asia Proceedings of Social Sciences}

(APSS)

www.readersinsight.net/APSS

\section{Research Objectives}

Aim

Investigate the nexus between SMEs and multidimensional poverty index and the moderating role of youth empowerment

\section{Purpose}

To look into the significance of SMEs in enabling households members have access to quality of education, good health and improving lining standard. Also, the extent to which youth empowerment strengthen the relationship between SMEs and multidimensional poverty reduction

\section{Objectives}

1. To examine the relationship between SMEs and multidimensional poverty reduction.

2. To investigate the moderating role of youth empowerment on the relationship between SMEs and multidimensional poverty reduction.

\section{Significance}

The study draws attention to key findings relating to the views of the SMEs owners on the contribution of their SMEs in reducing poverty. It is noteworthy to find that the participation of poor in SMEs activities though does not eradicate poverty, but help in reducing poverty to the bearable minimum. The study also contribute to a relatively novel body of youth empowerment as a moderator between SMEs and multidimensional poverty, which explores the significance of empowerment of the youth in making them business owners, job creators and above all alters their poverty status positively.

\section{Methodology}

The study used a quantitative survey approach to collect data from SMEs households in Niger State of Nigeria. A sample of 520 SMEs households was determined using Yamane (1967) simplified statistics. A cluster sampling technique is used to collect data from 8 Local Government Areas (LGAs) of Niger State, Nigeria. A total of 520 questionnaires are distributed to the households in the sampled LGAs, however, 432 (83\%) questionnaires was 


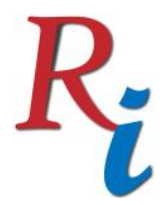

Asia Proceedings of Social Sciences

(APSS)

www.readersinsight.net/APSS

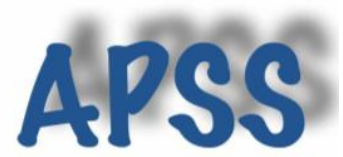

the valid sample for this study. The 8 LGAs include: Agaie, Bida, Lavun, Bosso, Gurara, Munya, Tafa and Rijau. Statistical Package for Social Science (SPSS) was used for descriptive analysis, while Smart Partial Least Square (PLS) 3.0 was used for confirmatory factor analysis (CFA) and structural equation modelling (SEM).

\section{Results}

\section{Measurement Model}

It was suggested that by Ramayah et al. (2017) that the convergent validity, the loading value and composite reliability should be greater than 0.7 and average variance extracted should be greater than 0.5 . The loading for youth empowerment $(0.952-0.987)$ and multidimensional poverty $(0.932-0.964)$ are both greater than the recommended vale of 0.7 . The measures of SMEs variable as a formative items depict the weight which ranges between $(-0.281-0.679)$. The composite reliability values for both youth empowerment (0.993) and multidimensional poverty (0.982) are exceedingly reliable. And that of average variance extracted exceeded the minimum recommended value. For the discriminant validity, it was suggested by Henseler and Chin (2010) that the indicators loadings should exceed the cross loadings. The results indicates the indicators loadings for youth empowerment (0.606) and multidimensional poverty (0.701) both exceeded their cross loadings.

\section{Structural Model}

The relationship between SMEs and multidimensional poverty reduction shows a positive nexus $(\beta=0.451, t-v a l u e=9.051)$ and as well the $t$-value is greater than $1.645(<0.05)$. The moderating effect of youth empowerment between SMEs and multidimensional poverty a robust relationship $(\beta=0.314$, $\mathrm{t}$-value $=2.462)$.

\section{Findings}

The findings from the study reveal that there is positive relationship between SMEs and multidimensional poverty reduction. The result is in consonant with previous studies such as Agyapong (2010); Garba (2012); Ioron (2014) and Asikhia (2016) who agrees that SMEs enable households to have access to quality education, good health and improving standard of living. The findings also established a robust moderating effect of youth empowerment 


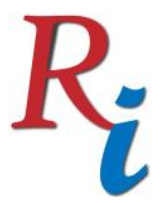

\section{Asia Proceedings of Social Sciences}

(APSS)

www.readersinsight.net/APSS

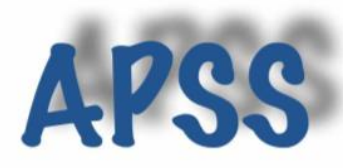

between SMEs and multidimensional poverty reduction. This outcome is in line with the earlier findings such as Todorovic et al. 2016); Shefiu 2016 and Ndamu 2017.

\section{Acknowledgement}

This work was supported by Ministry of Higher Education and Universiti Malaysia Sarawak [grant numbers F01/FRGS/1607/2017].

\section{References}

Agyapong, D. (2010). Micro, small and medium enterprises' activities, income level and poverty reduction in Ghana - A synthesis of related literature. International Journal of Business and Management, 5(12), 196-205.

Asikhia O. U. (2016). SMEs, wealth creation and poverty alleviation in Nigeria. Journal of Economics and Behavioral Studies, 8(4), 17-31.

Garba, A. S. (2012). Entrepreneurship, public policy and poverty reduction in Nigeria. International Journal of Business and Social Research, 2(2), 158-169.

Henseler, J., and Chin, W. W. (2010). A comparison of approaches for the analysis of interaction effects between latent variables using partial least squares path modelling. Structural Equation Modelling 17(1): 82-109.

Iorun, J. I. (2014). Evaluation of survival strategies of small and medium enterprises in Benue State, Nigeria. International Journal of Academic Research in Accounting, Finance and Management Sciences, 4(2), 255-263.

Ndamu, R. K. (2017). Impact assessment of government empowerment programmes on youths participation in entrepreneurial activities in Adamawa State-Nigeria. International Journal of Advanced Studies in Economics and Public Sector Management, 5(2), 66-80.

Ramayah, T., Yeap, J. A. L., Ahmad, N. H., Halim, H. A., and Rahman, S. A. (2017). Testing a confirmatory model of facebook usage in smartPLS using consistent PLS. International Journal of Business and Innovation, 3(2), 01-14.

Shefiu, R. (2016). Youth empowerment leveraging on entrepreneurship. Continental Journal of Sustainable Development, 7(1), 45-60. 


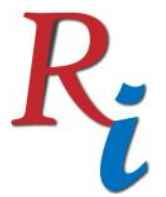

\section{Asia Proceedings of Social Sciences}

(APSS)

www.readersinsight.net/APSS

Todorovic, I., Komazec, S., Jevtic, M., Obradovic, V., and Maric, M. (2016). Strategic management in development of youth and women entrepreneurship - Case of Serbia. Organizacija, 49(4), 197-207.

Yamane, T. (1967). Statistics, an introductory analysis, (2nd Ed). New York: Harper and Row.

\section{Author's Biography}

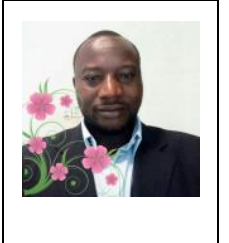

Musa Mohammed obtained his B.Sc.Economics and M.Sc. Economics from Usmanu Danfodiyo University Sokoto, Nigeria, then PhD in Development Economics from Universiti Malaysia Sarawak. He is presently Lecturer I, Department of Project Management Technology, Federal University of Technology, Minna, Niger State, Nigeria.

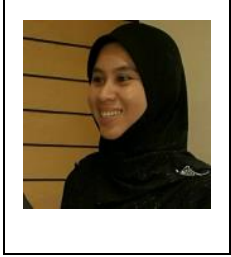

Rossazana Ab-Rahim earned her Bachelor of Economics degree, with honors, from Universiti Utara Malaysia (UUM), Sintok (1996). She obtained her MSc. degree in Economics from Surrey University, U.K. (1998). In 2011, she completed her PhD in Economics from Universiti Kebangsaan Malaysia (UKM). She is currently an Associate Professor at the Faculty of Economics and Business, Universiti Malaysia Sarawak (UNIMAS) and Deputy Dean of Graduate \& Research. Rossazana has expertise in the area of industrial economics, specifically efficiency and productivity and development economics. She has published in various journals, proceedings and chapters in books in the areas of industrial economics and applied economics. 